\title{
Kulturowe cele rozwoju naukowego. Misja uniwersytetu w koncepcji José Ortegi y Gasseta
}

\section{STRESZCZENIE}

W artykule podjęta została istotna obecnie kwestia określenia roli i miejsca uniwersytetu we współczesnym świecie. Procesy globalizacyjne wymuszają daleko idące zmiany w instytucjach społecznych, nie są wolne od nich również uniwersytety, dlatego konieczne jest odczytanie na nowo misji uniwersytetu w kontekście obecnych przemian kulturowych. Inspiracją do prowadzonych analiz są założenia społecznej teorii wypracowanej przez jednego z najbardziej wszechstronnych myślicieli XX w. - José Ortegę y Gasseta.

Wykorzystując metodę analityczno-syntetyczną, jak również częściowo historyczno-komparatywną, została ukazana aktualność głównych założeń sformułowanych przez Ortegę y Gasseta. Wśród nich najważniejsze miejsce zajmują postulaty dotyczące właściwego określenia misji uniwersytetu. Podstawową tezą jest rozróżnienie pomiędzy nauką a kulturą. O ile współczesna kultura bardzo mocno czerpie z nauki - głównie nauk technicznych i przyrodniczych - to jednak istotne jest rozróżnienie tych dwóch obszarów, przyznając priorytet kulturze. Z tego głównego założenia wypływa szereg logicznych konsekwencji związanych z koniecznymi zmianami profilu kształcenia uniwersyteckiego. Zdecydowanie większe znaczenie powinno mieć ogólne przygotowanie o profilu humanistycznym, które jest nie tylko wprowadzeniem w realia społeczne, ale i uwrażliwieniem na wartości wyższe. Kształcenie profesjonalistów - będących specjalistami wąskich dziedzin - nie może być pozbawione bowiem szerszego odniesienia do

1 Jarosław Charchuła, Wydział Nauk Pedagogicznych, Akademia Ignatianum w Krakowie, Polska, jaroslaw.charchula@ignatianum.edu.pl. 
kontekstu kulturowego. Uniwersytet będzie właściwie realizował swoją misję, jeżeli oprócz przygotowania zawodowego będzie potrafił przygotować swoich absolwentów do życia w społeczeństwie.

\section{Słowa kluczowe:}

kultura, nauka, społeczeństwo masowe, misja uniwersytetu, José Ortega y Gasset

\section{ABSTRACT}

The article deals with the important issue of defining the role and place of the university in the contemporary world. Globalization processes force far-reaching changes in social institutions, universities are also not free of them, so it is necessary to re-read the university's mission in the context of current cultural changes. The inspiration for the conducted analyzes are the assumptions of the social theory developed by one of the most versatile thinkers of the twentieth century - José Ortega y Gasset.

Using the analytical-synthetic method as well as the historical-comparative method, the topicality of the main assumptions formulated by Ortega y Gasset was demonstrated. Among them, the most important place is occupied by the postulates regarding the proper definition of the university mission. The basic thesis is the distinction between science and culture. While modern culture draws heavily on science - mainly technical and natural sciences - it is important to distinguish these two areas, giving decisive priority to culture. From this main assumption comes a number of logical consequences related to the necessary amendments to the university education profile. The general preparation of a humanistic profile, which is not only an introduction to the social reality but a sensitization to higher values, should definitely have greater significance. The education of professionals - specialists in narrow fields - can not be deprived of a broader reference to the cultural context. The University will properly implement its mission if, in addition to professional preparation, it will be able to prepare its graduates to live with others in the society.

\section{Keywords:}

culture, science, mass society, university mission, José Ortega y Gasset

\section{KONTEKST HISTORYCZNY}

Początki i rozwój uniwersytetów w Europie jest mocno powiązany ze zmianami struktury społecznej w XI i XII w. na skutek których mieszczaństwo przechodziło znaczące przeobrażenia i jego rola oraz pełnione publicznie funkcje znacznie się 
zwiększyły. W tym okresie w wielu miastach Włoch, Francji, a także Hiszpanii i Anglii powstają korporacje uczniów i nauczających ich mistrzów, które z czasem przekształcają się w uniwersytety. Ten historyczny kontekst ich powstania jest istotny, ponieważ jasno określał ich funkcje i pozycję w strukturze społecznej.

Krajem, który w znaczący sposób wpisał się w tę historię rozwoju uniwersytetów jest Hiszpania. Pierwszy uniwersytet powstał tam w 1218 r. w Salamance². Obecnie w Hiszpanii studenci kształcą się na 50 państwowych i 28 prywatnych uniwersytetach. Ważnym momentem w rozwoju szkolnictwa wyższego w Hiszpanii było przeniesienie Uniwersytetu Alcala do Madrytu na początku XIX w. Był to symboliczny moment, w którym rozpoczęło się odchodzenie od klasycznej formy uniwersytetu jako instytucji posiadającej rozbudowaną autonomię, na rzecz nowej, charakteryzującej się wysokim poziomem upaństwowienia i scentralizowania. W wyniku tych zmian uniwersytety stopniowo zaczęto traktować jako kolejną instytucję państwową. W ten sposób wyłonił się zbiurokratyzowany - w dużej mierze poddany kontroli państwa - nowy model kształcenia akademickiego. Spowodowało to jednak spadek jakości kształcenia i osłabienie całego systemu. Przedstawiciele wielu środowisk akademickich domagali się wówczas wdrożenia skutecznych reform. Wśród licznych intelektualistów tamtego okresu, którzy podejmowali te kwestie warto wymienić takie nazwiska jak Menendez Pelayo (1856-1912), Angel Ganivet (1865-1898) czy Miguela de Unamuno (1864-1936). Ważnym głosem w dyskusji na temat kształtu szkolnictwa akademickiego było stanowisko wyrażone przez José Ortegę y Gasseta (1883-1955). Założenia dotyczące tej problematyki, które zawarł w stworzonej przez siebie teorii społecznej, były szeroko komentowane przez liczne środowiska akademickie na całym świecie.

Przykład Hiszpanii dobrze pokazuje tendencje zmian, jakim podlegały w większości uniwersytety europejskie, choć z różnym nasileniem i na różnych etapach swojego rozwoju. Konsekwencje tych przemian bardzo mocno wpływały na realizowany model, a także jakość kształcenia akademickiego przez kolejne dekady. Zagadnienia te są szczególnie aktualne w kontekście toczącej się w Polsce debaty na temat kierunków i celów reformy szkolnictwa wyższego. Nie ulega wątpliwości, że zmiany w tym obszarze są konieczne. Może o tym świadczyć choćby fakt, że w najnowszym Akademickim Rankingu Uniwersytetów Świata (tzw. Lista szanghajska) z 2017 r., najlepsza polska uczelnia plasuje się dopiero w trzeciej setce. O ile niektóre kryteria oceny w tym rankingu mogą budzić uzasadnione

2 Niektóre źródła podają jako najstarszy uniwersytet ten powstały w Palencji między 1204 a 1208 r. Ze względu jednak na jego stosunkowo niewielki zasięg i niezbyt długi okres funkcjonowania bardziej uzasadnione jest wskazywanie w tym względzie na Uniwersytet w Salamance. 
wątpliwości, to jednak sam fakt tak odległej pozycji powinien mobilizować do szerokiej dyskusji w środowiskach akademickich, która przełoży się na realne i skuteczne działania.

Zwiększanie jakości i konkurencyjności kształcenia akademickiego w Polsce powinno odbywać się nie tylko poprzez profesjonalizowanie wąskich specjalności w ramach wybranych kierunków, ale i w połączeniu ze znacznie szerszym profilowaniem całego programu studiów, który musi uwzględniać kontekst kulturowy i oferować wysoki poziom w zakresie dyscyplin humanistycznych. Jeżeli uniwersytety mają kształcić i wychowywać przyszłe elity, to powinny na nowo zdefiniować swoje miejsce w strukturze społecznej i właściwie odczytywać misję, której istotnym elementem jest wprowadzania kolejnych pokoleń w świat kultury. Myśl ta stanowi główną tezę niniejszego artykułu i będzie rozwijana w dalszych jego częściach. Inspiracją i punktem odniesienia do tych rozważań będzie koncepcja wypracowana przez José Ortegę y Gasseta w kontekście przemian kulturowych, które doprowadziły do ukształtowania się społeczeństwa masowego i jego dominacji. W wyniku tych przemian znacząco zmienił się również profil kształcenia uniwersyteckiego realizowany przez uczelnie na całym świecie. Społeczna teoria wypracowana przez hiszpańskiego filozofa, uwzględniająca reformę uniwersytetów wydaje się być cennym głosem w obecnie prowadzonej debacie na temat kierunku reform szkolnictwa wyższego.

\section{ZNACZENIE KULTURY}

Aby właściwie zinterpretować koncepcję reformy uniwersytetu Ortegi y Gasseta, należy przybliżyć podstawowe założenia dotyczące jego koncepcji kultury. Zdaniem hiszpańskiego myśliciela właściwe odczytanie zadania, jakim jest życie, domaga się współdziałania z innymi osobami i korzystania z dorobku poprzednich pokoleń. Dzięki temu człowiek będzie mógł się odnaleźć w okolicznościach, w których funkcjonuje. Ortega y Gasset stwierdza bowiem w sposób jednoznaczny, że „kultura jest tym, co ratuje od życiowego zagubienia, co pozwala człowiekowi żyć bez zmarnowania swojego życia i skrajnego poniżenia”3 (Ortega y Gasset, 1930a, s. 321). Oznacza to, że kultura jest niczym innym, jak instrumentem życia, pomagającym być bardziej autentycznym.

3 „Cultura es lo que salva del naufragio vital, lo que permite al hombre vivir sin que su vida sea tragedia sin sentido o radical envilecimiento” (tłum. własne). 
Zasadniczą tezą hiszpańskiego myśliciela jest określenie człowieka jako bytu niepodlegającego w pełni racjonalnemu wytłumaczeniu. Ten nieodgadniony człowiek żyje teraźniejszością, jest otwarty na przyszłość, a przeszłość traktuje jako wciąż obecną w swoisty sposób w teraźniejszości. Zrozumienie obecnej teraźniejszości nadaje sens epistemologii przeszłości, która ułatwia interpretację nie tylko konkretnej historii indywidulanego człowieka, ale także historii społeczeństw. Życie ludzkie tworzy się bowiem zarówno w przestrzeni intymnej, jak i interpersonalnej. Życie zmusza człowieka do poszukiwań intelektualnych, aby odnaleźć uniwersalną koncepcję, która pomaga w interpretacji otaczającej go rzeczywistości społecznej (Ortega y Gasset, 1930a). Człowiek nie może żyć bez reagowania na otoczenie i intelektualnego reinterpretowania tego otoczenia. Nie wytwarza on całości idei, ale otrzymuje część z nich ze środowiska historycznego. Ten system pomysłów, który go inspiruje, jest kulturą (Ortega y Gasset, 1930a). Dlatego kultura będąca interpretacją ludzkiego życia jest, zdaniem hiszpańskiego myśliciela, tak istotna, jak samo życie (Ortega y Gasset, 1930a).

Nie mając jasnych idei człowiek fałszuje swoje istnienie, przestaje być autentyczny i dlatego, jak postuluje Ortega y Gasset, jedną z głównych misji uniwersytetu powinno być odpowiednie przygotowanie do autentycznego przeżywania swojego życia. Brak wychowania kulturowego powoduje, zdaniem hiszpańskiego myśliciela, wykształcenie pokolenia, którego przedstawiciela można określić mianem: „barbarzyński specjalista”4 (Ortega y Gasset, 1930b, s. 217). Należą do tego pokolenia osoby, które co prawda posiadają dużą wiedzę w swojej specjalizacji, ale nie posiadają wiedzy o podstawowych pojęciach, aby realizować swój życiowy projekt. Jest to, zdaniem Ortegi y Gasseta, główna cecha społeczeństwa masowego, którego przedstawiciele pomimo posiadania często wysokich kompetencji zawodowych, mają duże trudności z odnalezieniem się w zmieniającym się kontekście społeczno-kulturowym. Aby lepiej zrozumieć założenia reformy uniwersytetu, postulowanej przez Ortegę y Gasseta, należy przedstawić ogólną analizę uwarunkowań w jakich, jego zdaniem, ukształtowała się dominacja społeczeństwa masowego.

\section{SPOŁECZEŃSTWO MASOWE}

Według Ortegi y Gasseta, wraz ze zmianą historycznie uwarunkowanego sposobu życia - czyli zmianami dotyczącymi zarówno elementów struktury społecznej, jak również jej funkcji - ukształtowało się zjawisko mas. Powodem tego nie był

\footnotetext{
4 „Especialista bárbaro” (tłum. własne).
} 
znaczący wzrost populacji, ale zmiana zachowania. Masy zajęły przestrzenie społeczne i wypełniły miejsca publiczne. Wcześniej, zdaniem hiszpańskiego myśliciela, każdy żył zanurzony w swoich własnych sprawach, troszczył się o swoje własne życie (Ortega y Gasset, 1930b). W opinii Ortegi y Gasseta przeciętne życie człowiek należącego do mas charakteryzuje pustka moralna (1930b). Styl życia zmienił się w wyniku uksztaltowania się hiperdemokracji, gdzie bycie innym stało niepopularne czy wręcz niepożądane. Nie chodzi tu jednak o zacieranie pozornej różnorodności wyrażającej się w działaniach indywidualnych, jak na przykład strojach, ale o głębszy poziom utożsamienia, związany z powszechnie akceptowanymi interpretacjami rzeczywistości społecznej. Masa narzuca wspólny styl życia, nie poprzez ustanowione mechanizmy przedstawicielstwa politycznego, ale za pomocą różnego rodzaju presji narzucając swoje upodobania i aspiracje (Ortega y Gasset, 1930b). Hiszpański myśliciel mówi w tym kontekście o zjawisku kontroli społecznej, które powoduje, że każdy, kto nie dopasowuje się do większości zostaje wykluczony i odsunięty na margines (Ortega y Gasset, 1930b).

Życie autentyczne natomiast to dla filozofa coś innego niż postrzega to masa (Carvalho, 1943). Życie prawdziwie ludzkie jest jedyne, przeżyte w pierwszej osobie i tylko dzięki temu może być autentyczne. To, co nadaje sens życiu, to wierność intymnemu elementowi człowieka. Oznacza to, że życie jest w swojej esencji ryzykiem i samotnością (Ortega y Gasset, 1930b). Nowy człowiek, który reprezentuje społeczeństwo masowe, według hiszpańskiego myśliciela, utracił perspektywę prawdziwie autentycznego życia, co spowodowało kryzys cywilizacji. Aby pokonać kryzys cywilizacji konieczne jest, zdaniem Ortegi y Gasseta, przezwyciężenie tego typu człowieka, który pojawiał się w społeczeństwie masowym, a możliwe to jest poprzez odnowienie procesu kulturalnego i edukacyjnego (Ortega y Gasset, 1930a). Zmiany, które proponuje hiszpański filozof są bardzo szeroko zakrojone, ponieważ konieczne jest głębokie przemodelowanie sposobu myślenia człowieka masowego, który jest zafascynowany osiągnięciami technologii i zadowolony z tego, co ma do dyspozycji, ale nie zdaje sobie sprawy z cierpienia, ryzyka i smutków związanych z wysiłkiem włożonym w ich produkcję. Jest nieświadomy wysiłku i zagrożeń życia, przez co przyzwyczaja się do fałszywego poczucia bezpieczeństwa, co z kolei prowadzi go do zmniejszania wymagań wobec siebie. W związku z tym, że człowiek masowy obniża poprzeczkę oczekiwań wobec siebie, staje się także mniej wymagający w stosunku do przejawów kultury kreowanej publicznie. Fakt ten powoduje, że Ortega y Gasset uważa, iż w momencie kiedy człowiek masowy staje się centralną figurą przestrzeni społecznej, następuje degeneracja życia publicznego i przewartościowanie pożądanych wzorów zachowań (Ortega y Gasset, 1930b). 
Inną cechą człowieka masowego, zdaniem Ortegi y Gasseta, jest bycie specjalistą z konieczności nałożonej przez praktykę nowoczesnej nauki. Ten wymóg zmienia go automatycznie w człowieka masowego, robi z niego nowoczesnego barbarzyńcę. Człowiek ten jest taki, ponieważ wie dużo z zakresu niewielkiego obszaru wiedzy. Nauczył się wyrafinowanej techniki lub wymagającego zawodu, ale jest ignorantem we wszystkim innym (Ortega y Gasset, 1930a). Życie człowieka masowego jest nieautentyczne ponieważ jest oddalone od esencji życiowej, czyli twórczego napięcia, które towarzyszy poszukiwaniom nowych rozwiązań w chwilach ograniczonego poczucia bezpieczeństwa. Autentyczność może zostać odzyskana przez nowe pokolenie, które w inny sposób stawi czoła esencji życia (Ortega y Gasset, 1914). W koncepcji Ortegi y Gasseta, jedynie reforma sposobu kształceniu może pomóc w pokonaniu nieautentyczności życia i kryzysu cywilizacji.

Jednak problem jest bardziej złożony niż opracowanie nowych programów nauczania. Jak stwierdza hiszpański filozof, podstawowa trudność to poczucie braku sensu, dezorientacja pokolenia, które nie dostrzega zagrożeń czyhających w życiu (Ortega y Gasset, 1923a). Problem zatem nie ogranicza się do treści nauczania, ale chodzi o coś dużo bardziej złożonego, człowiek nieautentyczny bowiem nie ma programu życia ani motywacji, żeby go przygotować.

\section{GŁÓWNE ZAŁOŻENIA REFORMY UNIWERSYTETU}

Człowiek masowy prowadzi nieautentyczne życie, ponieważ jego definicja życia, zdaniem Ortegi y Gasseta, jest nieprawdziwa. Wśród przyczyn takiego stanu rzeczy, hiszpański myśliciel wskazuje przede wszystkim na nieodpowiednią edukację akademicką, dlatego zakłada jej gruntowną reformę. Proponuje on powierzenie uniwersytetowi roli dotyczącej zmiany sposobu interpretowania nauki oraz kultury, której niewłaściwe zdefiniowanie spowodowało dominację człowieka masowego. Ortega y Gasset zakłada, że korzenie reformy uniwersyteckiej tkwią w pełnym dopasowaniu jego misji do zmieniających się okoliczności (Ortega y Gasset, 1923b). Misja ta, co warto podkreślić, ma dla Ortegi y Gasseta zarówno wymiar indywidualny, jak i publiczny. Chodzi bowiem o to, aby pojedynczy człowiek i całe społeczeństwa byli w stanie właściwie interpretować okoliczności, w których funkcjonują (Ortega y Gasset, 1910).

Warto zwrócić uwagę jeszcze na rozróżnienie, które postulował w tym kontekście Ortega y Gasset, dotyczące podziału na profil edukacji przeznaczony z jednej strony dla profesjonalistów, co wiązało się uzyskaniem uprawnień do wykonywania 
określonego zawodu, a z drugiej strony natomiast dla tak zwanych badaczy, których zadaniem było rozwijanie naukowego aspektu kultury (Ortega y Gasset, 1930a). Ze względu na proponowany przez Ortegę y Gasseta program refom uniwersytetu pierwszoplanowe znaczenie ma tutaj rola jaką przypisuje on badaczom. Zdaniem hiszpańskiego myśliciela być badaczem, to odkrywać jasne idee na temat szeroko rozumianych okoliczności, w których się żyje oraz przekazywać je innym. Według Ortegi y Gasseta kultura jest tym, co ratuje człowieka od rozbicia życiowego i pozwala mu uniknąć życia radykalnie zdegradowanego (Ortega y Gasset, 1927). Jest tak ponieważ to w kulturze człowiek odnajduje życiowe wartości swojego istnienia, repertorium przekonań napędzających jego działania.

Ortega y Gasset przedstawia badacza jako człowieka zdolnego do poznania żywej idei na temat mechanizmów świata społecznego, przy czym nie chodzi tutaj o specjalistyczną wiedzę zawodową, ale o ideę, która jest podstawą szerszego spojrzenia na dziedzictwo kulturowe uwzględniające dorobek przeszłych pokoleń. Wyłączna znajomość elementów typowych dla zawodu to jedna z przyczyn powstania człowieka masowego. Wykształcenie uniwersyteckie proponowane przez Ortegę y Gasseta powinno być szerokie i wystarczające do zwalczania zjawiska mas. W jego trakcie studenci powinni zostać wprowadzeni w podstawowe elementy autentycznie rozumianej kultury (Ortega y Gasset, 1940). Kiedy uniwersytet traci charakter kulturowy, przestaje być tym, czym w swej esencji jest i staje się nieautentyczny, tak jak sam człowiek masowy. W tym kontekście hiszpański myśliciel podnosi kwestię odpowiedniego definiowania nauki, która jego zdaniem nie jest tylko przekazywaniem praw, formuł i teorii. Stoi on na stanowisku, że nauka to badanie, stawiania problemów i praca nad ich rozwiązaniem oraz dotarcie do rozwiązania (Ortega y Gasset, 1911).

Kryzys cywilizacji pojawia się, gdyż przeciętny człowiek nie jest w stanie sprostać wyzwaniom swoich czasów, powodując tym samym epokę zaniku autentycznie rozumianej kultury. Aby z tym walczyć należy, zdaniem Ortegi y Gasseta, rozróżnić wykształcenie kulturowe od przygotowania zawodowego, jako że oba zależą od nauki, która jest nieodłącznie związana z przeznaczeniem człowieka (Ortega y Gasset, 1907).

\section{ZAŁOŻENIA REFORMY DOTYCZACEE STUDENTA}

Wiele nieporozumień, zdaniem Ortegi y Gasseta, które narosły na przestrzeni wieków na uniwersytecie i w innych instytucjach edukacyjnych, wynikało z przekonania, że to studenci i ich szczególne warunki muszą być najważniejszą podstawą, 
aby zbudować ramy funkcjonowania dla instytucji nauki (Ortega y Gasset, 1906). Hiszpański myśliciel stoi na stanowisku, że jeżeli nauczanie na poziomie uniwersyteckim jest przeznaczone dla przeciętnego studenta, koniecznym jest dokładne sprawdzenie, co uniwersytet zamierza go nauczyć. Wystarczy przeanalizować program nauczania dowolnej uczelni, aby zdać sobie sprawę z niemożliwości przyswojenia tak olbrzymiej ilości wiedzy przez przeciętnego człowieka. Dlatego Ortega twierdzi, odnosząc się do jemu współczesnych czasów, że „obecny uniwersytet jest czystym i konstytucyjnym nadużyciem, ponieważ jest kłamstwem”5 (Ortega y Gasset, 1930a, s. 326). Stąd dla hiszpańskiego myśliciela nieuniknionym jest porzucenie tego utopijnego pragnienia nauczania tego, czego powinno się uczyć i ograniczenia się tylko do tego, czego można się nauczyć. Uniwersytet, który jest instytucjonalną projekcją studenta, nigdy nie powinien zapominać o sile nabywczej jego wiedzy i tego, co naprawdę powinien wiedzieć, aby móc żyć. To minimum, które uczeń powinien przyswoić, określa się jako to, co jest absolutnie niezbędne dla życia człowieka. Jak stwierdza Ortega y Gasset student „nie powinien uczyć się niczego poza tym, czego naprawdę może się nauczyć”6 (Ortega y Gasset, 1930a, s. 334).

W tym kontekście hiszpański myśliciel analizuje wewnętrzną trudność studiowania. Zaczyna od założenia, że współczesna mu koncepcja studiowania oparta jest na pewnym fałszywym podejściu. Ten, kto zamierza zgłębiać jakąś naukę, nie kwestionuje jej treści, przyjmuje ją jako prawdę i martwi go jedynie jej przyswojenie. Z drugiej strony ten, kto odczuwa autentyczną potrzebę poznania, podchodzi do tej wiedzy pełen podejrzeń i poddaje ją krytyce, ponieważ nie wierzy w to, co już zostało zrobione właśnie dlatego, że sam chce odkryć tę prawdę (Ortega y Gasset, 1933). Taki człowiek odnawia naukę i ma predyspozycje do tego, aby zostać badaczem, a nie tylko uzyskać kwalifikacje do wykonywania zawodu. Niestety, zdaniem Ortegi y Gasseta, na uniwersytetach dominuje postawa związana z przygotowaniem zawodowym. Studiowanie jest wtedy zewnętrzną i wymuszoną potrzebą. Wówczas „bycie studentem jest jak bycie płatnikiem podatków, jest czymś »sztucznym«, do czego jest się zmuszonym” (Ortega y Gasset, 1933, s. 551).

5 „la Universidad actual es un puro y constitucional abuso porque es una falsedad” (tłum. własne).

6 „no se debe enseñar sino lo que se puede de verdad aprender” (tłum. własne).

7 „ser estudiante, como ser contribuyente, es algo »artificial« que el hombre se ve obligado a ser" (tłum. własne). 
Według Ortegi y Gasseta taka sytuacja powinna być punktem wyjścia dla reformy edukacji. Studiowanie jest samo w sobie czymś fałszywym, a nauczanie akceptuje to kłamstwo. Tak więc student nie uczy się, a nawet gdy to robi, nie przynosi mu to korzyści, ponieważ jego celem jest spełnienie formalnych wymogów zmierzających do pozyskania kwalifikacji zawodowych. Ortega y Gasset dostrzega w tym fakcie poważną dysocjację pomiędzy autentyczną wiedzą a przeciętnym człowiekiem, ponieważ kultura lub wiedza odpowiadają na intymną potrzebę, której zaspokojenia nie można odłożyć na później. Jeśli nie stanowi to autentycznej potrzeby, to przekazywana kultura nie ma głębokiej podstawy w przeciętnym człowieku i jest pełna martwych idei, które są czymś narzuconym. W konsekwencji tego „pod otrzymaną kulturą, ale nie prawdziwie przyswojoną, człowiek pozostanie nietknięty, to znaczy pozostanie niewykształcony, pozostanie barbarzyńcą”» (Ortega y Gasset, 1933, s. 551). Ten problem można rozwiązać, zdaniem hiszpańskiego myśliciela, sprawiając, że uczeń odczuje potrzebę nauki, która jest mu przekazywana. Uczeń autentyczny będzie tym, który uczy się motywowany koniecznością życiową, a nie formalnym warunkiem określonego kierunku studiów. Niemożliwe jest to jednak bez odpowiednio przygotowanych profesorów, którzy nie tylko przekazują wiedzę, ale i wprowadzają we właściwie rozumianą kulturę.

\section{ROLA NAUCZYCIELA AKADEMICKIEGO}

Postać autentycznego profesora uniwersytetu jest, zdaniem Ortegi y Gasseta, mocno zdeterminowana poprzez misje uniwersytetu i specyficzne warunki studenta. Jak stwierdza hiszpański myśliciel, profesor musi być niekwestionowanym mistrzem uniwersalnej wiedzy, ponieważ bardziej niż ktokolwiek będzie uosabiał kulturalny wymiar uniwersytetu; musi być autentyczny, ponieważ to on ma wpoić studentom tę intelektualną żądzę kultury, która jest podstawową rzeczą sprawiającą, że ludzkie życie jest godne przeżycia (Ortega y Gasset, 1930a). Jest to niezbędny warunek, aby nauczyciel akademicki odnalazł swoje miejsce w czasach, w których żyje i aby posiadał aktualną kulturę, w którą będzie potrafił skutecznie wprowadzić swoich studentów.

Ponadto cechą nauczyciela akademickiego, na którą wskazuje również Ortega y Gasset, jest kompetentne nauczanie konkretnej nauki. Tutaj musimy wziąć

8 „por debajo de la cultura recibida, pero no auténticamente asimilada, quedará intacto el hombre; es decir quedará inculto; es decir, quedará bárbaro” (tłum. własne). 
pod uwagę ekonomię nauczania hiszpańskiego myśliciela, który proponuje, aby nauczano tylko tego, co jest niezbędne do życia studenta i co on naprawdę potrafi przyswoić. To prawo powinno kierować wszystkimi autentycznymi nauczycielami w ich nauczaniu. Ta zasada ekonomii w nauczaniu implikuje inny rodzaj niezbędnego talentu każdego dobrego nauczyciela, którym jest zdolność do tworzenia energicznej syntezy wiedzy. Nauczyciel powinien inicjować w swoich studentach spontaniczną i prawdziwą troskę o pytania nauki, którą im przekazuje. Tylko w ten sposób będą oni w stanie zrozumieć odpowiedzi, które są udzielane na te pytania (Ortega y Gasset, 1908).

Dla Ortegi y Gasseta nauczanie to nie tylko przekazywanie nauki, ale ukazywanie potrzeby tej nauki. Dlatego bycie badaczem nie wystarczy, aby być dobrym nauczycielem, ponieważ nie chodzi tu o nauczanie metody badań. Talent badawczy idący w parze ze zdolnością dokonywania syntez i autentycznym powołaniem pedagogicznym stanowi idealne połączenie cech prawdziwego nauczyciela (Ortega y Gasset, 1906). Ten, kto jest tylko badaczem, nie może być dobrym nauczycielem, ponieważ badania są czymś indywidualnym i prywatnym, a nauczanie najczęściej oznacza dla niego utratę cennego czasu. Ortega y Gasset nie chce przez to powiedzieć, że nie można znaleźć dobrego nauczyciela pośród badaczy, ale jest to rzadkie, ponieważ badania są czymś zasadniczo indywidualnym i prywatnym, a nauczanie jest czymś społecznym i komunikatywnym.

Mówiąc o ukazywaniu potrzeby nauki, Ortega y Gasset odnosi się do zainteresowania, które nauczyciel powinien obudzić w uczniu przez nauczany przedmiot. Ta umiejętność wzbudzania zainteresowania musi być istotną cechą autentycznego nauczyciela (Ortega y Gasset, 1933). Dlatego nauczanie nie powinno być zwykłą komunikacją tego, co zostało powiedziane lub napisane przez kogoś innego. Konieczne jest przedstawienie uczniowi problematycznego charakteru nauki i sprawienie, aby poczuł się częścią poszukiwanych rozwiązań. Według założeń Ortegi y Gasseta uniwersytet zajmuje aktywną pozycję w życiu publicznym i w związku z tym nauczyciel powinien promować tę działalność oraz prowadzić swoich uczniów i pomagać im w kształtowaniu społecznego sumienia, niezbędnego do prawidłowego wykonywania ich przyszłej pracy zawodowej (Ortega y Gasset, 1910).

Podsumowując można stwierdzić, że autentyczny nauczyciel powinien być człowiekiem, posiadającym solidną i aktualną kulturę oraz specjalizującym się w konkretnej wiedzy, która inspiruje go do twórczego działania. Oprócz tego zawsze musi pamiętać, że jest on częścią zdeterminowanego społeczeństwa i że tworzy przyszłe pokolenia, które muszą być przygotowane do swej nieodwołalnej misji historycznej. Nie tylko człowiek staje się nieautentyczny, tracąc zdolność 
twórczego reagowania na problemy jego współczesności, ale także instytucje społeczne narażone są na to samo ryzyko, kiedy nie realizują swojej misji. Dlatego Ortega y Gasset wskazuje drogę, na której uniwersytet może realizować swoją misje i przeciwdziałać kryzysowi cywilizacji charakteryzującemu się dyktatem kultury masowej.

Podstawową tezą, na poparcie której zaprezentowane są liczne argumenty w kolejnych częściach prowadzonych w tekście analiz, jest rozróżnienie pomiędzy nauką a kulturą. O ile współczesna kultura, w szerokim rozumieniu, mocno czerpie z nauki - głównie nauk technicznych i przyrodniczych - to jednak istotne jest rozróżnienie tych dwóch obszarów, przyznając priorytet kulturze. Z tego głównego założenia wypływa szereg logicznych konsekwencji związanych z koniecznymi zmianami profilu kształcenia uniwersyteckiego. Zdecydowanie większe znaczenie powinno mieć ogólne przygotowanie o profilu humanistycznym, które jest nie tylko wprowadzeniem w realia społeczne, ale i uwrażliwieniem na wartości wyższe. Kształcenie profesjonalistów - będących specjalistami wąskich dziedzin - nie może być pozbawione bowiem szerszego odniesienia do kontekstu kulturowego. Uniwersytet będzie właściwie realizował swoją misję, jeżeli oprócz przygotowania zawodowego będzie potrafił przygotować swoich absolwentów do życia w społeczeństwie. Celem uniwersytetu powinno więc być kształcenie kulturowe, szersze niż tylko nauczanie zawodowe i naukowe. To ostatnie jako forma odpowiedzi na wyzwania stawiane przez „problemy życia codziennego” jest bowiem integralną częścią wykształcenia kulturowego i stanowi jego istotny, choć niedominujący element składowy. Zachowanie odpowiednich proporcji - pomiędzy kształceniem kulturowym a przygotowaniem zawodowym - stworzy odpowiednie uwarunkowania społeczne tak dla zwiększania kompetencji zawodowych, jak również dla utrzymania właściwej dynamiki rozwoju kulturowego. W tym kontekście założenia przedstawione przez Ortegę y Gasseta wydają się słuszne i mogą stanowić cenne źródło inspiracji do podejmowanych obecnie tak szeroko dyskusji na temat kierunku reform szkolnictwa wyższego w Polsce i Europie.

\section{Bibliografia}

Abellán, J.L. (2000). Ortega y Gasset y los orígenes de la transición democrática. Madrid: Espasa-Calpe.

Cacho, V. (2000). Los intelectuales y la política. Perfil público de Ortega y Gasset. Madrid: Biblioteca Nueva.

Castelló, M. (2009). La hermenéutica narrativa de Ortega y Gasset. Granada: Comares. 
Cerezo, G.P. (2011). José Ortega y Gasset y la razón práctica. Madrid: Biblioteca Nueva /Fundación José Ortega y Gasset - Gregorio Marañón.

Ferreiro, L.I. (2005), La teoría social de Ortega y Gasset: los usos. Madrid: Biblioteca Nueva.

Gaj, R. (2007), Ortega y Gasset. Warszawa: Wiedza Powszechna.

Gray, R. (1994). José Ortega y Gasset: el imperativo de la modernidad. Madrid: Espasa-Calpe.

Lasaga, M.J. (2006). Figuras de la vida buena: ensayo sobre las ideas morales de Ortega y Gasset. Madrid: Enigma.

Marias, J. (2004). História da filosofia. São Paulo: Martins Fontes.

Marias, J. (1958). La Universidad, Realidad problemática. Obras completas, t. 4. Madrid: Revista de Occidente.

Orringer, N.R. (1999). La filosofía de la corporalidad en Ortega y Gasset. Pamplona: Universidad de Navarra.

Ortega y Gasset, J. (1958). Obras completas, 6 tomos. Madrid: Revista de Occidente (wszystkie przywołane w artykule pozycje tego autora zostały zaczerpnięte z niniejszej publikacji a przy każdej pozycji umieszczonej w bibliografii został wskazany rok wydania, numer tomu i zakres stron):

Ortega y Gasset, J. (1908). Asamblea para el progreso de las ciencias. T. 1, s. 99-110.

Ortega y Gasset, J. (1923a). El tema de nuestro tiempo. T. 1, s.141-203.

Ortega y Gasset, J. (1927). Espíritu de la letra. T. 3, s. 513-599.

Ortega y Gasset, J. (1940). Ideas y Creencias. T. 5, s. 463-474.

Ortega y Gasset, J. (1906). La pedagogía del paisaje. T. 1, s. 53-57.

Ortega y Gasset, J. (1910). La pedagogía social como programa político. T. 1, s. 503-521.

Ortega y Gasset, J. (1914). Meditaciones del Quijote. T. 1, s. 309-400.

Ortega y Gasset, J. (1930a). Misión de la Universidad. T. 4, s. 311-353.

Ortega y Gasset, J. (1923b). Pedagogía y anacronismo. T.1, s. 731-733.

Ortega y Gasset, J. (1930b). Rebelión de las masas. T.4, s. 3-310.

Ortega y Gasset, J. (1933). Sobre el estudiar y el estudiante, T. 4, s. 545-554.

Ortega y Gasset, J. (1907). Sobre los estudios clásicos. T. 1, s. 63-67.

Ortega y Gasset, J. (1911). Una respuesta a una pregunta. T. 1, s. 211-215.

Parente, L. (2013) Ortega y Gasset e la "vital curiosidad" filosófica. Milán: Mimesis.

Polit, K. (2005). Kryzys cywilizacji Zachodu w myśli José Ortegi y Gasseta. Lublin: Wydawnictwo Uniwersytetu Marii Curie-Skłodowskiej.

San, M.J. (1998) Fenomenología y cultura en Ortega. Ensayos de interpretación. Madrid: Tecnos.

San, M.J., La fenomenología de Ortega y Gasset. Madrid: Biblioteca Nueva / Fundación José Ortega y Gasset. 